\title{
Isolation, Identification and Antibiogram of Mannheimia hemolytica Associated with Caprine Pneumonia in the Cauvery Delta Region of Tamil Nadu, India
}

\author{
P. Ponnusamy ${ }^{1 *}$, B. Samuel Masilamoni Ronald ${ }^{1}$, M. Ranjith Kumar $^{2}$ and R. Manickam ${ }^{1}$ \\ ${ }^{1}$ Department of Veterinary Microbiology, Veterinary College and Research Institute, \\ Orathanadu, Thanjavur -614 625, Tamil Nadu, India \\ ${ }^{2}$ Department of Veterinary Medicine, Madras Veterinary College, \\ Chennai-600 007, Tamil Nadu, India \\ *Corresponding author
}

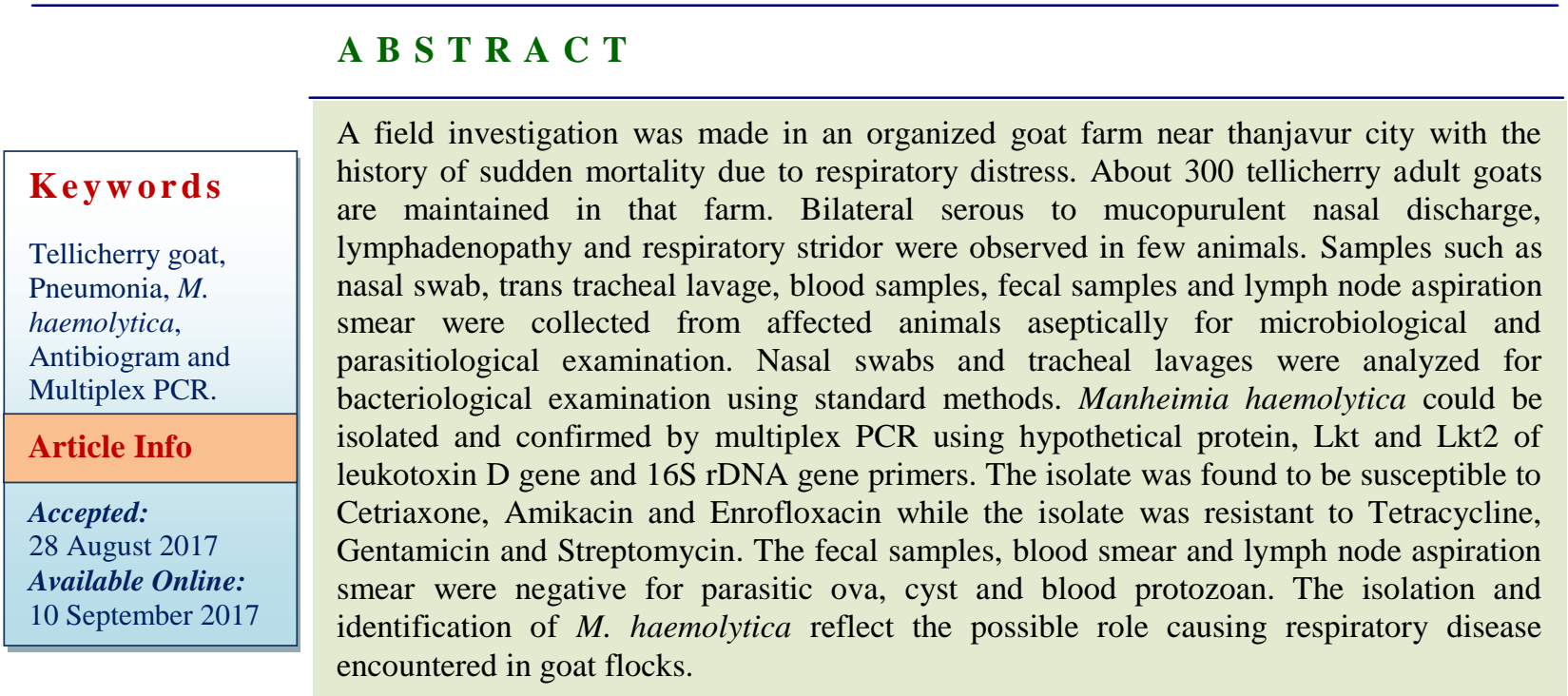

\section{Introduction}

Pneumonia is defined as inflammation of the pulmonary parenchyma and most commonly encountered respiratory problems in small ruminants throughout the world (Ackermann and Brogden, 2000). In goat herds, pneumonia increases production costs associated with expensive treatments which cause economic burden to small and marginal farmers. Though pneumonia is generally fatal in kids, infections and deaths also happen in adult animals. The respiratory infections contribute 5.6 percent of total diseases of small ruminants irrespective of etiology (Hindson and Winter, 2002). Respiratory infections of goats are multifactorial (Lacasta et al., 2008). The bacterial, viral, fungal, parasitic and other managemental factors are related with pneumonia in goats. Bacterial agents such as Pasteurella multocida, Mannheimia haemolytica, Mycoplasma species, Streptococcus pneumoniae, Arcanobacterium pyogenes and Bordetella parapertussis cause respiratory infections in small ruminants (Brogden et al., 1998; 
Ackermann and Brogden, 2000; Berge et al., 2006; Yener et al., 2009). The pneumonic pasteurellosis in goats are mainly caused by Mannheimia haemolytica and Pasteurella multocida which leads to significant reduction in growth performance (Brogden et al., 1998, Emikpe et al., 2013). Pasteurella haemolytica biotype A was renamed as Mannheimia which contain several species including $M$. haemolytica, M. granulomatis, M. glucosida, $M$. ruminalis and $M$. varigena (Angen et al., 1999a). M. haemolytica is a gram-negative coccobacilli, non-motile, non-spore forming, fermentative and bipolar organism (Chen et al., 2002). Diagnosis of M. haemolytica by molecular methods yields rapidity and sensitivity compared to conventional cultural and biochemical tests. In the present study pneumonia associated with $M$. haemolytica could be isolated and confirmed by multiplex PCR and antibiotic sensitivity of that isolate was also determined.

\section{Materials and Methods}

\section{Sample collection}

Samples such as nasal swab, trans tracheal lavage, blood samples, fecal samples and lymph node aspiration smear were collected from affected animals aseptically for microbiological and parasitiological examination. The samples were transported under cold condition to the laboratory for bacterial isolation.

\section{Bacteriological examination}

The samples were inoculated into blood agar, MacConkey agar, PPLO broth and incubated aerobically for 24 hours at $37^{\circ} \mathrm{C}$. Small narrow zone hemolytic colonies were observed in blood agar and colonies were subjected to gram staining and routine biochemical tests were carried out (Quinn et al., 1994). Antimicrobial susceptibility testing can be carried out by disc diffusion method using tetracycline, sulfadiazine, enrofloxacin, streptomycin, ciprofloxacin, amikacin, ceftriaxone and gentamicin antibiotic discs.

\section{DNA extraction}

DNA was extracted from the suspected colony by thermal lysis method. One or two colonies from the suspicious cultures were picked up and suspended into $1.5 \mathrm{ml}$ of micro centrifuge tube containing $50 \mu \mathrm{l}$ of molecular grade water. The tube was placed in a boiling water bath for 10 minutes followed by snap chilling and centrifugation at $13000 \mathrm{rpm}$ for 5 minutes. Without disturbing the pellet, the supernatant was removed and stored at $-20^{\circ} \mathrm{C}$ until for further analysis.

\section{Multiplex PCR}

Multiplex PCR was performed in a Thermocycler (Master Cycler nexus gradient) in a total reaction volume of $25 \mu$ l containing $12.5 \mu \mathrm{l}$ ampliqon master mix $(2 \mathrm{x})$ and using already published $1 \mu \mathrm{M}$ of primer sets shown in table 1 (Alexander et al., 2008) and $3 \mu \mathrm{l}$ of template sample DNA. PCR procedure was performed as follows; $95^{\circ} \mathrm{C}$ for 15 minutes; 40 cycles of $94^{\circ} \mathrm{C}$ for $30 \mathrm{~s}, 60^{\circ} \mathrm{C}$ for $30 \mathrm{~s}$, $72^{\circ} \mathrm{C}$ for $30 \mathrm{~s}$ and final extension of $72^{0} \mathrm{C}$ for 10 minutes.

\section{Parasitological examination}

The fecal samples were screened for parasites affecting the small ruminants by the routine procedures. Further, blood smear and lymph node aspiration smear were examined for blood protozoan parasites.

\section{Results and Discussion}

\section{Bacterial isolation}

M. haemolytica $(75 \%)$ followed by other bacterial agents Staphylococcus spp. (10\%), E. coli (5\%) and Proteus spp. (10\%), were 
also isolated from nasal swab and $M$. haemolytica $(80 \%)$ and E. coli $(20 \%)$ were isolated from trans tracheal lavages shown in table 2. The majority of the isolate was $M$. haemolytica. Further Mycoplasma bacterial growth was not observed in PPLO broth after 14 days of incubation.

Mannheimia spp. isolates identified by culture and biochemical tests were subjected to multiplex PCR using hypothetical protein, Lkt and Lkt2 of leukotoxin D gene and 16S rDNA gene primer sets which gave positive results for M. haemolytica shown in figure 1 .

On the basis of these results, $M$. haemolytica was the most common cause of respiratory disease outbreaks in goat flocks.

The antibiotics resistance pattern showed that the isolate was found to be susceptible to Cetriaxone, Amikacin and Enrofloxacin while the isolate was resistant to Tetracycline, Gentamicin and Streptomycin.

Fig.1 Multiplex PCR for detection and differentiation of Mannheimia haemolytica from other species. M- DNA Ladder (100bp), 1- E. coli, 2 -Proteus spp., 3 - Mannhemia haemolytica (HP - 90bp, LKT -206bp, 16S rDNA -304bp)

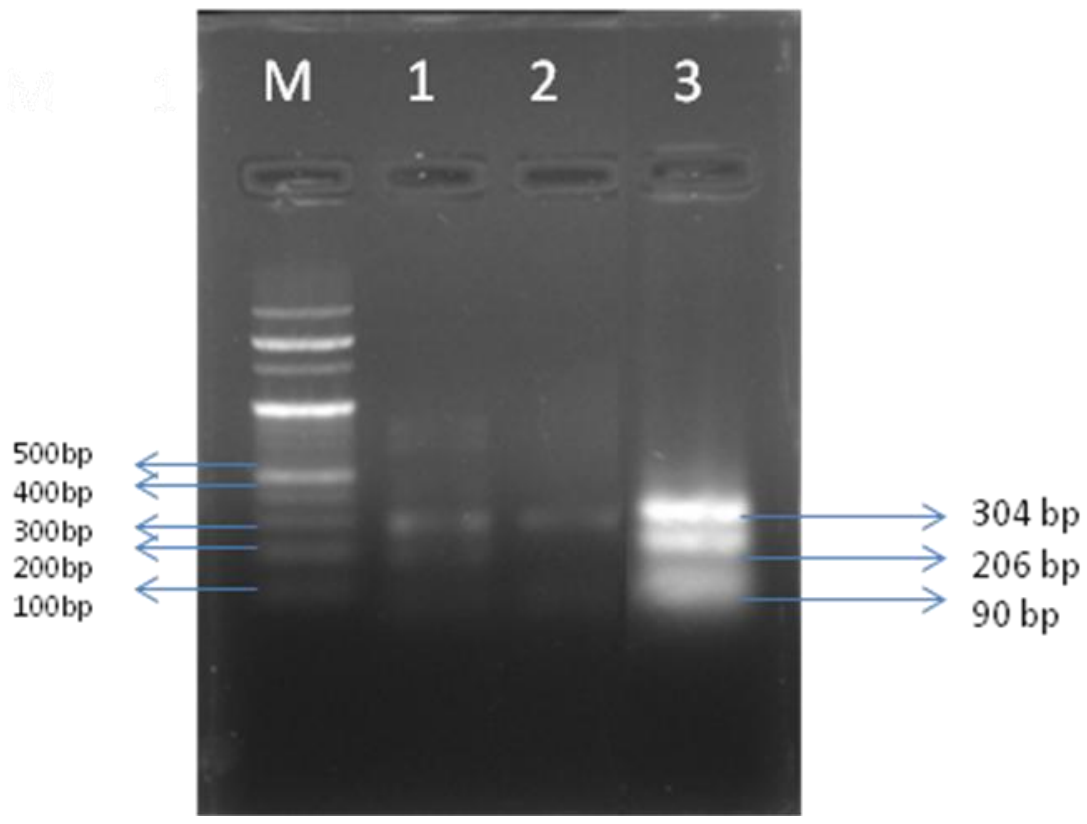

Table.1 Primers used in this study

\begin{tabular}{|l|l|l|l|}
\hline Target gene & Primer sequence & Size & Reference \\
\hline LKT & $\begin{array}{l}\text { GCAGGAGGTGATTATTAAAGTGG } \\
\text { CAGCAGTTATTGTCATACCTGAAC }\end{array}$ & $206 \mathrm{bp}$ & Alexander et al., 2008 \\
\hline LKT2 & $\begin{array}{l}\text { CTCTCTTTAGAAAAGCTGGAAAAC } \\
\text { TTTTGCCAAGTGGTGTATTGC }\end{array}$ & $170 \mathrm{bp}$ & Alexander et al., 2008 \\
\hline HP & $\begin{array}{l}\text { CGAGCAAGCACAATTACATTATGG } \\
\text { CACCGTCAAATCCTGTGGATAAC }\end{array}$ & $90 \mathrm{bp}$ & Alexander et al., 2008 \\
\hline $16 \mathrm{~S}$ rDNA & $\begin{array}{l}\text { GCTAACTCCGTGCCAGCAG } \\
\text { CGTGGACTACCAGGGTATCTAATC }\end{array}$ & $304 \mathrm{bp}$ & Alexander et al., 2008 \\
\hline
\end{tabular}


Table.2 Frequency and percentage of bacterial species isolated from clinical samples

\begin{tabular}{|l|l|c|c|}
\hline Samples & Bacterial species & Frequency & Percentage (\%) \\
\hline Nasal swab & Mannheimia spp. & 15 & 75 \\
\hline & Staphylococcus spp. & 2 & 10 \\
\hline & E.coli & 1 & 5 \\
\hline & Proteus spp. & 2 & 10 \\
\hline Trans tracheal lavages & Mannheimia spp. & 4 & 80 \\
\hline & E.coli & $\mathbf{1}$ & $\mathbf{2 0}$ \\
\hline
\end{tabular}

\section{Parasitological examination}

No parasitic ova, cyst and blood protozoan parasites were detected in fecal samples, blood smear and lymph node aspiration smear.

Respiratory tract infection in small ruminants is the major cause of economic burden in marginal and landless farmers in India. Pathogens like bacteria, virus and parasites have been occupied in the development of respiratory disease along with stress factors. Stress factors such as transport, overcrowding, poor housing conditions and environmental changes cause respiratory insult which result in decline in the immune status of the small ruminants and thereby supporting the number of bacterial, viral, and parasitic diseases to break down the tissue defense barriers (Rahal et al., 2014). Due to loss of natural defense mechanism, goats are highly susceptible to Pasteurella spp. and Mannheimia spp. which are commensals in the respiratory tract. $M$. haemolytica cause important respiratory tract disease in ruminants and small ruminants (Highlander 2001).

The virulence factors associated with pathogenicity of $M$. haemolytica are leukotoxin (LKT), lipopolysaccharide, adhesions, capsule, outer membrane proteins and various proteases. Out of these virulence factors, leukotoxin (LKT) which is species specific, lipopolysaccharide are considered as most important virulence factor for pulmonary colonization, evasion of immune response and establishment of infection (Singh et al., 2011). In this study, already published primers derived from HP, Lkt and Lkt2 and 16S rDNA genes which amplifying hypothetical protein, different regions of the leukotoxin D gene and universal bacterial sequences were used respectively (Alexander et al., 2008). Isolates were designated as $M$. haemolytica by positive amplification of HP, Lkt, 16S rDNA genes, M. glucosida (HP, Lkt, Lkt2, 16S) and $M$. ruminalis (HP, 16S). Molecular methods yield high specificity and sensitivity compared to cultural methods for detection of Mannheimia spp. (Catry et al., 2004). Multiplex PCR is employed to distinguish $M$. haemolytica from other bacterial species (Alexander et al., 2008) since serotyping is not a consistent tool for differentiating strains of Mannheimia spp. (Jaramillo-Arango et al., 2008).

In the present study, $M$. haemolytica could be isolated from respiratory disease outbreaks in goat flocks in the Cauvery delta region of Tamil Nadu. It is further confirmed by multiplex PCR as a rapid and preferred detection method for differentiation of $M$. haemolytica from other bacterial species compared to cultural and serotyping methods.

\section{References}

Ackermann, M. R., and Brogden, K. A. 2000. Responses of the ruminant respiratory tract to Mannheimia (Pasteurella) haemolytica. Microbes and Infection, 2(9), 1079-1088. 
Alexander, T.W., S.R. Cook, L.J. Yanke, C.W. Booker, P.S. Morley, R.R Read, S.P. Gow and McAllister, T.A. 2008. A multiplex polymerase chain reaction assay for the identification of Mannheimia haemolytica, Mannheimia glucosida and Mannheimia ruminalis. Vet Microbiol. 130(1-2):165-75.

Angen, O., R. Mutters, D.A. Caugant, J.E. Olsen and Bisgaard, M. 1999a. Taxonomic relationships of the Pasteurella haemolyticacomplex as evaluated by DNA-DNA hybridizations and 16S rRNA sequencing with proposal of Mannheimia haemolytica comb. nov., Mannheimia granulomatis comb. nov., Mannheimia glucosida sp. nov., Mannheimia ruminalis sp. nov. and Mannheimia varigena sp. nov. Int. J. Syst. Bacteriol. 49: 67-86.

Berge, A.C., W.M. Sischo and A.L. Craigmill, 2006. Antimicrobial susceptibility patterns of respiratory tract pathogens from sheep and goats. J. Am. Vet. Med. Assoc. 229: 12791281.

Brogden, K.A., H.D. Lehmkuhl and Cutlip, R.C.1998. Pasteurella haemolytica complicated respiratory infections in sheep and goats. Veterinary Research.29(34):233-254.

Catry, B., M. Baele, G. Opsomer, A. de Kruif, A. Decostere and Haesebrouck, F. 2004. tRNAintergenic spacer PCR for the identification of Pasteurella and Mannheimia spp. Vet Micro biol. 98: 251-260.

Chen H.I., Hulten K., Clarridge J.E. Taxonomic subgroups of Pasteurella multocida correlate with clinical presentation. J. Clin. Microbiol. 2002; 40:3438-3441.

Emikpe, B.O., P.N. Tanko, O.M. Onilude and Sabri, M.Y. 2013. The influence of dexamethasone treatment and successive road transport stress on the occurrence of caprine pneumonia in a hot humid tropical environment. Vet World. 6(8):497-501.

Highlander, S. K., 2001. Molecular genetic analysis of virulence in Mannheimia (Pasteurella) haemolytica. Front Biosci.6:D1128-D1150.

Hindson, J.C., and Winter, A.C.2002. Respiratory disease in Manual of Sheep Diseases, pp. 196-209, Blackwell Science, Oxford, UK, 2nd edition.

Jaramillo-Arango, C.J., R. Hernández-Castro, F. Suárez-Güemes, J.J Martínez-Maya, F. Aguilar-Romero, L. Jaramillo-Meza and Trigo, F.J.2008. Characterisation of Mannheimia spp. strains isolated from bovine nasal exudate and factors associated to isolates, in dairy farms in the Central Valley of Mexico. Res. Vet. Sci. 84: 7-13.

Lacasta, D., L.M. Ferrer, J. J. Ramos, J. M. Gonz'alez and De las Heras, M.2008. Influence of climatic factors on the development of Pneumonia in lambs. Small Ruminant Research, 80(1-3): 28-32.

Quinn, P.J., M.E. Carter, B. Markey and Carter, G.R. 1994. Bacterial pathogens: microscopy, culture and identification in clinical veterinary microbiology. Wolfe Publishing, London. pp. 21-60.

Rahal, A., A.H. Ahmad, A. Prakash, R. Mandil and Aruna T. Kumar. 2014. Environmental Attributes to Respiratory Diseases of Small Ruminants. Veterinary Medicine International.

Singh, K., J.W. Ritchey and Confer, A. W.2011. Mannheimia haemolytica: bacterial-host interactions in bovine pneumonia. Vet Pathol. 48(2):338-48.

Yener, Z., Z. Ilhan and Y.S. Saglam, 2009. Immunohistochemical detection of Mannheimia (Pasteurella) haemolytica antigens in goats with natural pneumonia. Vet. Res. Commun. 33: 305-313.

\section{How to cite this article:}

Ponnusamy, P., B. Samuel Masilamoni Ronald, M. Ranjith Kumar and Manickam, R. 2017. Isolation, Identification and Antibiogram of Mannheimia hemolytica Associated with Caprine Pneumonia in the Cauvery Delta Region of Tamil Nadu. Int.J.Curr.Microbiol.App.Sci. 6(9): 3118-3122. doi: https://doi.org/10.20546/ijcmas.2017.609.385 